\title{
PERANAN MODAL SOSIAL DALAM KEGIATAN EKONOMI
}

\author{
Pheni Chalid \\ UIN Syarif Hidayatullah Jakarta \\ pheni.chalid@uinjkt.ac.id
}

\begin{abstract}
Trust in business is a fundamental element within capital and business success. Businesses need social interaction and networking. Hierarchical mechanism in the corporation, on the one hand aims to streamline the corporate performance targets in the pursuit of profit, but on the other hand there is the critical issue of how the relationship between the shareholders or the investors in monitoring the performance and behavior management in running the company. The problems is simply to look for answers from the existence of a contract containing agreements and management job descriptions, so that the irregularities that occurred outside the context of the contract will be consequential sanctions. The problem is, if then the existence of the contract will streamline the monitoring of behavior and performance management, which all it really comes down to mutual trust relationship, between management and shareholders.
\end{abstract}

Keywords: Trust; Investment; Social Capital

\begin{abstract}
Abstrak
Kepercayaan dalam bisnis merupakan elemen mendasar dalam suatu kesuksesan bisnis. Bisnis membutuhkan interaksi sosial dan jaringan. Mekanisme hirarki dalam suatu perusahaan, di satu sisi bertujuan untuk mencapai target kinerja perusahaan dalam meraih keuntungan, tetapi di sisi lain isu kritis yang muncul ialah bagaimana membangun jaringan di antara para pemangku kepentingan atau perusahaan dalam mengawasi kinerja dan prilaku manajemen dalam menjalankan perusahaan. Permasalahan ini dapat dijawab dengan mudah dengan kehadiran kontrak kerjasama dan deskripsi pekerjaan, sehingga penyimpangan yang muncul di luar kontrak dapat dikenakan sanksi. Permasalahannya ialah jika segala sesuatu hanya berdasarkan pada kontrak kerjasama, lalu dimana kepercayaan sebenarnya akan muncul diantara manajemen dan para pemangku kepentingan.
\end{abstract}

Kata Kunci: Kepercayaan; Investasi; Modal Sosial 


\section{PENDAHULUAN}

Trust atau kepercayaan adalah perilaku sosial yang berlaku dan dipraktikkan masyarakat secara umum dan terus menerus. Trust merupakan kepercayaan yang diperoleh dari interaksi dan pengalaman yang diberikan penafsiran oleh orang yang mengalaminya secara langsung. Oleh karena itu, trust bersifat fluktuatif dan personal. Proses ini dialami oleh hampir semua orang sepanjang hidupnya. Oleh karena itu subjek yang menjadi pokok perhatian dalam tulisan ini adalah trust dalam pemahaman sosial (social trust), bukan trust terhadap pemerintah atau trust terhadap institusi sosial lainnya (institutional trust). Trust sosial secara logis berbeda antara trust terhadap institusi atau otoritas politik seperti misalnya partai politik. Trust sosial lebih mengarah pada bagaimana trust sebagai sebuah nilai mampu mengikat masyarakat dalam sebuah jaringan yang luasnya ditentukan seberapa kental trust yang dibangun. Trust yang dipraktikkan sehari-hari secara sosial berfungsi sebagai modal bagi kegiatan-kegiatan ekonomi.

\section{TRUST DALAM MASYARAKAT: TINJAUAN KONSEPTUAL}

Interaksi merupakan pembahasan penting karena aktifitas ini menjadi fokus utama kehidupan manusia. Banyak factor yang menyebabkan manusia berhubungan dengan orang lain atau entitas yang berada di luar dirinya. Sejak lahir, interaksi menjadi kebutuhan penting bagi individu karena interaksi merupakan upaya manusia mengatasi keterbatasannya dalam memenuhi kebutuhan dan keinginannya. Setidaknya inilah yang menjadi daya dorong manusia untuk berhubungan dengan sesamanya. Banyak di antara kita beranggapan interaksi yang dilakukan terlepas dari ekspektasi dan pretensi. Kita juga sering melihat bagaimana seseorang dengan nyaman berbagi rahasianya kepada seseorang, tapi tidak menceritakannya kepada orang lain. Atau pada tingkatan yang lebih berisiko lagi, seseorang menitipkan kekayaannya kepada sebuah lembaga dengan hanya mendapatkan tanda bukti beberapa lembar kertas yang disebut dokumen. Dari beberapa contoh dalam interaksi yang kita temui sehari-hari muncul pertanyaan mendasar, apa yang membuat orang rela melakukan hal-hal yang berisiko bagi dirinya, dan dia menyadari risiko tersebut? 
Masyarakat sebagai individu pada dasarnya menyadari keterbatasanketerbatasannya. Inilah alasan mendasar mengapa manusia berinteraksi satu sama lainnya. Interaksi manusia didorong dan dibimbing oleh berbagai hal. Jika kita memandang dari aspek bahwa motivasi manusia melakukan interaksi adalah kesadaran akan keterbatasannya, atau karena terkondisi untuk selalu membutuhkan entitas lain di luar dirinya. Hal ini dapat dianalisis melalui interaksionisme-simbolik yang berakar pada pragmatisme. Mead (dalam Ritzer, 2007) mengungkapkan bahwa seseorang memahami sebuah nilai bukan dari proses mental yang terisolasi, tapi berasal dari interaksi. Perhatian utama Mead tertuju pada bagaimana manusia mempelajari simbol selama interaksi pada umumnya dan selama proses sosialisasi pada khususnya. Jadi perhatiannya bukan pada bagaimana manusia menciptakan arti dan simbol. Karena itu, manusia akan mempelajari apa yang menguntungkan dan tidak menguntungkan bagi dirinya.

Pada tingkat kemasyarakat yang lebih khusus Mead mengungkapkan bahwa masyarakat memiliki sejumlah pemikiran tentang pranata sosial (social institution). Masyarakat bagi Mead berarti proses sosial tanpa henti yang mendahului pikiran dan diri. Individu bergerak ke arah di mana institusi dan kebiasaan terbentuk tanpa sempat berpikir secara mendalam terlebih dahulu. Individu cenderung mengadopsi, mempelajari dan menjalankan apa yang menjadi pengalaman dan pengamatannya. Meskipun individu memiliki kemungkinan menyesuaikan diri atau menciptakan nilai bagi dirinya, tapi kemampuan tersebut seringkali tidak mudah untuk dimanifestasikan. Pendidikan merupakan jalan untuk menginternalisasi nilai atau kebiasaan bersama komunitas ke dalam diri manusia. Pendidikan dan pengasuhan yang dialami manusia sejak kecil menjadi nilai inti yang sulit untuk dipupuskan. Nilai inti merupakan nilai yang menjadi pedoman dasar manusia dalam menjalani kehidupannya. Nilai inti tersebut antara lain agama, budaya, bahasa, tradisi, alat produksi dan sistem prestise yang berkembang dan diwariskan antar generasi. Penekanan Mead yang relatif lebih kuat pada analisis pengalaman sosial dalam memahami kehidupan sosial. Individu seolah berada dalam teritori yang membatasi secara sosial dan psikologis, menjadi suatu identitas dan atribut yang tidak lekang oleh waktu dan diwariskan antar generasi. Beberapa aspek 
dari nilai dan institusi sosial tersebut mengalami perubahan, tetapi tidak secara keseluruhan. Kecuali dalam situasi yang luar biasa dan terjadi evolusi nilai dalam jangka waktu yang sangat panjang, seperti misalnya budaya Sumeria yang kini hilang dan tidak lagi digunakan, hanya dapat dipelajari dari peninggalan aftefak dan manuskrip yang tersisa.

Interaksi dalam perspektif interaksionisme-simbolik menyatakan secara tegas bahwa individu berinteraksi berdasarkan pengetahuannya tentang simbol yang disepakati dan dipahami. Blumer memasukkan sosial-struktural dan sosialkultural seperti "sistem sosial", "struktur sosial", "kultur", "posisi status", "peran sosial", "adat", "institusi", "perwakilan kolektif", "situasi sosial", "norma sosial", dan "nilai" yang secara operasional dipraktikkan dengan bahasa, sistem religi, adat, kultur, dan nilai yang menjadi identitas dan atribut suatu kelompok.

Nilai-nilai yang dipelajari dan pengalaman sosial individu inilah yang menjadi jembatan interaksi. Maka, individu pertama kali cenderung berinteraksi dengan individu lain yang secara alamiah terbentuk dan memiliki pengalaman sosial yang sama. Oleh karena itu, interaksi manusia yang paling dekat adalah hubungan darah yang diperoleh melalui kelahiran. Pada interaksi inilah manusia mengadopsi bahkan mengimitasi nilai yang suatu saat menjadi pedoman di masa depannya melalui orangtuanya. Maka, berdasarkan teori interaksionisme simbolis Mead, keseluruhan sosial mendahului pemikiran individual baik secara logika maupun secara temporer. Kelompok sosial muncul lebih dulu, dan kelompok sosial menghasilkan perkembangan kesadaran individual.

Faktor penting yang berpengaruh dan interaksi adalah orang memiliki perasaan yakin dan nyaman dalam berinteraksi pada awalnya. Oleh karena itu, secara tradisional masyarakat berinteraksi berdasarkan pengalaman sosial, dan melahirkan kecenderungan berinteraksi secara intensif hanya kepada orangorang di lingkar terdekat. Mengenal secara lebih baik merupakan alasan pertama orang untuk berinteraksi. Melalui pengalaman sosial dan interaksi secara individual, pada saat yang bersamaan muncul pula yang disebut sebagai kepercayaan (trust).

Trust muncul sebagai dampak dari interaksi sosial. Keterikatan sosial pada dasarnya merupakan manifestasi dari hadirnya kepercayaan dalam interaksi. Munculnya kelompok-kelompok dan perasaan in-group hanya dapat 
terbentuk karena adanya kepercayaan antar individu (mutual-trust). Yang menjadi pertanyaan besar yaitu bagaimanakah kepercayaan terbentuk dan apa pengaruhnya dalam interaksi masyarakat yang semakin kompleks?

Masyarakat secara keseluruhan diikat dalam organisasi-organisasi sosial, seperti yang diungkapkan oleh Durkheim. Tipe solidaritas yang berkembang dalam masyarakat terbagi atas dua bentuk yaitu solidaritas mekanik dan organik. Pada solidaritas mekanik orang diikat karena kepercayaan bersama yang dibentuk atas dasar ikatan-ikatan tradisional. Ikatan darah seperti kekeluargaan, kekerabatan, daerah, tradisi dan agama. Cita-cita bersama dibangun atas dasar komitmen moral dan keyakinan yang sama. Solidaritas mekanik terjadi pada masyarakat homogen yang khas pedesaan. Sementara itu, solidaritas organik merupakan ikatan masyarakat yang dibangun oleh motivasi ekonomi dan terjadi pada masyarakat heterogen khas perkotaan. Ketergantungan masing-masing ditentukan oleh seberapa besar produktifitas yang dihasilkan oleh individu. Solidaritas sosial dalam pandangan Durkheim pada kenyataaannya tidak berdiri sendiri. Setiap kelompok masyarakat diikat oleh nilai yang mempersatukan mereka.

Nilai-nilai yang disosialisasikan dan dikembangkan pada fase awal adalah nilai primer yang sangat mempengaruhi pola hubungan sosial individual di masa depan, termasuk persepsi kepercayaan. Kepercayaan termasuk elemen yang tumbuh bersama yang ditentukan oleh akumulasi pengalaman, persepsi dan derajad serta kedalaman interaksi sosial. Kepercayaan pertama kali akan diberikan kepada orang-orang yang berada di lingkar terdekat dan terdalam dalam hidup seseorang. Maka, kepercayaan ini dapat kita sebut sebagai kepercayaan primer (primary trust) atau kepercayaan tradisional (traditional trust). Kepercayaan yang tumbuh dan berkembang karena interaksi primer atau kepercayaan yang berakar pada primordialisme.

Kepercayaan primer atau trust primer yang berbasis pada sentimen primordial berkembang pada masing-masing individu dan terus berlangsung sepanjang hidupnya. Hal ini disebabkan karena hubungan darah, kekerabatan etnis dan agama merupakan relasi yang cukup kokoh dan satu sama lain memiliki ikatan kepercayaan yang tinggi yang tidak lekang oleh waktu. Kekuatan kepercayaan primer ditopang karena kuatnya modal pembentuk kepercayaan 
yang melekat pada diri individu sejak lahir. Kita tidak dapat memilih identitas kita saat dilahirkan. Karenanya, sebelum bersentuhan dengan dunia yang sebelumnya tidak dikenal, kita akan terlebih dahulu berinteraksi dengan orangorang di dekat kita. Secara natural interaksi awal individu pasti dengan orangtuanya dan orang-orang yang berada di lingkaran orangtuanya. Dengan risiko seperti ini, mau tidak mau kita akan sangat tergantung dan membutuhkan perlindungan orang yang berada di dekat kita. Orang-orang terdekat adalah kunci untuk memahami dan mengakses dunia luar. Jadi, trust primer adalah trust yang terbentuk secara natural dan kultural. Artinya pembentukan kepercayaan disebabkan karena kedekatan lokalitas sekaligus psikologis yang menciptakan rasa aman dari dunia luar kelompok yang awalnya dipandang asing dan kurang dikenal. Pemahaman, persepsi, nilai dan pengetahuan terhadap trust akan selalu merujuk pada persepsi trust yang diperoleh dari fase kehidupan primernya.

\section{KEJUJURAN, RESIPROSITAS DAN TRUST}

Trust adalah pelumas yang penting bagi sistem sosial. Sangat efisien; meminimalkan masalah yang timbul akibat perkataan orang lain sampai tingkat ketergantungan yang adil. Sayangnya, trust bukan komoditas yang dapat diperjualbelikan dengan mudah. Jika anda harus membelinya, anda pada dasarnya memiliki keraguan tentang apa yang ada beli. Trust dan nilai-nilai yang kurang lebih sama, kesetiaan atau berkata jujur, adalah contoh yang dikatakan para ekonom sebagai "eksternalitas". Trust dan nilai tersebut katakanlah merupakan barang, komoditas; mereka memiliki nilai ekonomis yang bersifat praktis; trust meningkatkan efisiensi dari sebuah sistem, memungkinkan anda untuk memproduksi barang-barang atau apapun yang anda miliki dengan harga tinggi. Tapi trust bukanlah komoditas yang dapat diperdagangkan di pasar walaupun secara teknik dimungkinkan dan berharga.

Kenneth Arrow

Interaksi dimungkinkan terjadi karena diawali oleh trust dan interaksi berlangsung secara terus menerus juga disebabkan oleh trust. Kesadaran bahwa manusia mengalami keterbatasan dalam memenuhi kebutuhan dan kelangsungan hidupnya membuat manusia harus berinteraksi secara mendalam dengan orang lain yang berada di luar kelompok primernya. Dapat dibayangkan jika kita tidak memiliki trust kita tidak akan membukakan pintu atau 
mempersilakan masuk kepada orang yang bertamu. Tanpa trust kita tidak akan memutuskan apakah kita akan menceritakan persoalan kita atau bahkan sekadar meminjamkan alat tulis. Yang menjadi pertanyaan besar, bagaimana trust dapat muncul dan secara umum menjadi properti sosial yang mampu memiliki daya ungkit terhadap keputusan yang diambil. Dalam trust kita memasukkan risiko dalam keputusan, di samping juga pada saat yang bersamaan kita melakukan kalkulasi untuk bahwa keputusan tersebut dilakukan untuk meminimalkan risiko. Seseorang mengambil risiko dengan menceritakan permasalahannya kepada temannya. Dengan mengambil tindakan tersebut ia memiliki harapan untuk mendapatkan dukungan moral sekaligus menanggung risiko bahwa orang yang diceritakan akan menanggapi secara negatif atau dapat juga menceritakan kembali kepada orang lain secara diam-diam. Namun ia mengambil risiko tersebut karena terdapat trust yang lebih besar daripada kekhawatiran bahwa orang yang diajak bicara dapat memberi perspektif dan sumbangan pemikiran atau setidaknya dapat meringankan perasaannya. Keputusan ini diambil berdasarkan pengalaman sehari-hari dalam berinteraksi dengan orang dengan latar belakang yang berbeda.

Trust sosial menurut Putnam (2001) terbentuk karena ditunjang oleh resiprositas dan kejujuran. Resiprositas atau hubungan timbal balik adalah nilai dan sistem moral dalam masyarakat. Resiprositas yang dipahami secara umum (generalized reciprocity) pada prinsipnya dimanifestasikan dalam tindakan seperti seseorang membantu orang lain saat ini, tanpa mengharapkan apapun dalam waktu dekat dan mungkin pula tanpa memberitahu Anda, yakin bahwa suatu saat di jalan Anda atau orang lain akan membalasnya.

Norma resiprositas umum adalah nilai fundamental dalam membentuk peradaban dimana seluruh nilai-nilai moral esensial tentang kesetaraan antara memberi dan menerima dan membalas tindakan tersebut terdapat dalam resiprositas. Tocqueville menggarisbawahi bahwa demokrasi dapat dibangun bukan karena masyarakat tidak mengikuti aturan ideal tentang pengorbanan (selflessness), tapi lebih dari itu karena mereka mengejar "kepentingan pribadi yang sangat dipahami". Artinya, memberi kontribusi terhadap komunitas pada dasarnya diorientasikan untuk mengamankan kepentingan diri. Dan tindakan ini disadari oleh masing-masing individu. Tindakan kolektif menjaga kebersihan 
lingkungan esensinya adalah menghindari dari lingkungan yang kotor dan tidak terjaga kesehatannya. Lingkungan yang baik akan berpengaruh positif terhadap orang yang tinggal di wilayah tersebut. Jika kesadaran ini dimiliki secara kolektif, di mana masing-masing menyadari dan mengupayakan menjaga lingkungan. Sistem sosial secara tidak langsung berpengaruh terhadap berkurang risiko dan biaya-biaya tidak langsung seperti biaya kebersihan dan kesehatan.

\section{TRUST DALAM INVESTASI}

Trust pada masyarakat tradisional terutama dilekatkan pada individu, keluarga dan etnis. Trust terbentuk karena adanya kedekatan lokasi tinggal, hubungan kekerabatan, dan interaksi yang intensif. Semakin lama berinteraksi, terlebih dalam interaksi tersebut masing-masing pihak merasakan adanya keuntungan yang diperoleh, maka trust semakin menguat. Jika pertukaran yang terjadi dalam kelompok seimbang dan dirasakan manfaatnya, maka reputasi pelaku akan semakin tinggi. Artinya, orang-orang yang konsisten dalam hubungan timbal-balik, misalnya jika dibantu memanen ia akan membalas dengan perlakuan yang seimbang maka orang-orang yang seperti ini memiliki reputasi yang baik di mata masyarakat.

Menghindari perilaku oportunis seperti ingkar, masyarakat menerapkan sanksi kultural yang mengikat. Dengan diterapkannya sanksi sosial, maka masing-masing anggota yang terikat kontrak sosial akan mematuhi aturan main. Anggota masyarakat menjatuhkan sanksi sosial jika seseorang menghindar dari tanggung jawab kelompok. Bentuk sanksi sosial mulai dari yang paling sederhana seperti sindiran halus, hingga yang paling berat yaitu pengucilan dan isolasi oleh seluruh anggota kelompok.

Seiring dengan perkembangan masyarakat dan intervensi teknologi, semakin kuat pula pengaruhnya terhadap pergeseran nilai dalam masyarakat. Hubungan ekonomi menjadi lebih transparan, dan pertukaran semakin menemukan bentuk yang eksak. Meskipun demikian, resiprositas tidak serta merta hilang begitu saja.

Trust dalam bisnis merupakan modal dan elemen dasar dalam kesuksesan bisnis. Bisnis membutuhkan interaksi sosial dan jaringan kerja. Granovetter (1992) dalam membangun teori kemelekatan ekonomi 
(embeddedness), berargumentasi bahwa melalui jaringan kerja akan memproduksi trust. Selanjutnya trust bekerja sebagai faktor yang melestarikan hubungan antara pelaku-pelaku bisnis yang terintegrasi dalam jaringan kerja. Dalam korporasi, bisnis sangat membutuhkan jaringan kerja dalam membesarkan cakupan korporasi yang merekrut banyak orang dan lintas pelaku. Kepemilikan terhadap badan usaha mulai beralih dari kepemilikan sendiri oleh pribadi menjadi kepemilikan bersama oleh publik. Kepemilikan bersama dalam korporasi dijalankan melalui mekanisme shareholders.

Operasionalisasi korporasi dijalankan oleh mekanisme hirarki. Pemiliki perusahaan tidak serta menjalankan perusahaan. Akan tetapi perusahaan dioperasikan melalui mekanisme representatif yang diwakili oleh pihak manajemen yang terdiri dari para profesional, yang ditunjuk atau dipilih oleh dewan atau komisaris. Melalui mekanisme hirarkis tersebut, manajemen bekerja membesarkan korporasi sesuai dengan tujuan perusahaan dan memberikan keuntungan kepada shareholders.

Mekanisne hirarkis dalam korporasi, di satu sisi bertujuan mengefektifkan kinerja korporasi dalam mengejar target keuntungan, namun di sisi lain terdapat persoalan kritis mengenai bagaimana hubungan antara shareholders atau para investor dalam mengawasi kinerja dan perilaku manajemen dalam menjalan perusahaan. Problematika tersebut secara sederhana dapat dicarikan jawabannya melalui keberadaan kontrak yang berisikan kesepakatankesepakatan dan deskripsi tugas manajemen, sehingga penyimpangan yang terjadi diluar konteks kontrak akan berkonsekuensi sanksi. Masalahnya, apakah kemudian keberadaan kontrak akan mengefektifkan pengawasan terhadap perilaku dan kinerja manajemen, yang semua itu sebenarnya bermuara pada hubungan saling mempercayai, antara manajemen dengan shareholders.

Keberadaan kontrak tidak selalu menjadi jaminan terhadap ketiadaan praktek penyimpangan dalam perusahaan. Praktek penyimpangan dalam perusahaan tidak saja terjadi antara pihak manajemen terhadap shareholders namun bisa terjadi antara korporasi dengan stakeholders. Penyimpangan yang terjadi dalam perusahaan biasanya terkait dengan manipulasi sistem dan pelaporan keuangan yang merugikan secara langsung terhadap shareholders 
dan secara tidak langsung terhadap stakeholders dan tentunya berdampak besar terhadap jatuhnya tingkat kepercayaan pasar terhadap perusahaan.

Dalam dunia bisnis dan investasi yang berkembang dewasa ini, trust beralih dari orang per orang kepada kertas. Dokumen yang memuat laporan dan aturan-aturan rinci menjadi sumber trust. Laporan keuangan yang ditujukan kepada pemegang saham atau masyarakat yang disahkan oleh sebuah kantor akuntan publik bergengsi menjadi sumber trust di mana orang atau institusi tergerak untuk menginvestasikan uangnya dalam jumlah yang sangat besar. Kegiatan ekonomi bergerak karena adanya perjanjian hitam di atas putih atau yang lazim dikenal sebagai kontrak. Walaupun kontrak formal terjalin setelah adanya kesepakatan informal dan hubungan yang cukup lama.

Kegiatan ekonomi yang berlangsung saat ini menunjukkan bahwa trust tetap memegang peranan penting. Dalam kertas kerja H. Dyer dan Chu (1997) "The Economic Value of Trust in Supplier-Buyer Relations" mengungkapkan bahwa hubungan kepercayaan mampu menekan biaya transaksi (transaction cost), mempermudah tukar menukar informasi dan meningkatkan hubungan investasi yang lebih spesifik di antara 435 pemasok automotif di Jepang dan Amerika Serikat yang dijadikan sampel penelitian. Tujuan penelitian H. Dyer dan Chu adalah ingin mencari jawaban terhadap tiga pertanyaan yang menjadi pokok permasalahan dalam investigasi mereka terhadap hubungan antara performance dan trust dalam relasi jual beli antara pemasok dan pembeli. Ketiga pertanyaan tersebut yaitu apakah pemasok memiliki tingkat kepercayaan yang tinggi terhadap pembeli. Jika kepercayaan itu telah terbentuk sedemikian rupa, maka, pertama, akan menyebabkan biaya transaksi yang rendah, kedua, saling berbagi informasi, dan ketiga mendorong investasi yang lebih besar daripada dengan pemasok yang memiliki tingkat kepercayaan yang rendah.

Asumsi yang dibangun dalam penelitian tersebut adalah organisasi atau perusahaan tidak mungkin dapat mempercayai organisasi atau perusahaan lain, karena dilihat sebagai kompetitor. Basis trust adalah pada individu, oleh karena itu trust hanya dapat diletakkan oleh indvidu kepada individu lainnya atau kelompok yang menjadi partner. Namun demikian, tidak menutup kemungkinan individu dalam organisasi atau perusahaan dapat berbagi orientasi dengan individu di organisasi atau perusahaan lain. Perspektif tersebut memberikan 
gambaran luas bahwa terdapat kepercayaan yang dianut secara kolektif oleh kelompok organisasi akan membuka peluang adanya kerjasama perusahaan. Kepercayaan biasanya dianggap memiliki nilai ekonomis ketika ia tidak dilembagakan dalam bentuk kontrak yang bersifat mekanis. Alasan mengapa trust lebih memiliki nilai ekonomis ketika ia tidak berwujud kontrak, karena dengan demikian ia mampu mengeliminasi kebutuhan terhadap formalitas kontrak, yang memerlukan biaya, pengawasan dan penegakkan. Jadi trust dipercayai mampu mereduksi biaya transaksi yang harus dikeluarkan.

Bagi para pebisnis, relasi bisnis itu sendiri adalah jaminan terbaik. Trust yang meluas (extended trust) dibangun ketika interaksi dalam perusahaan semakin kompleks dan saling ketergantungan semakin meningkat. Bersamaan dengan semakin besarnya skala kegiatan ekonomi. Secara bersamaan namun dengan cara yang berbeda, trust akan tumbuh beriringan dengan sanksi. Hal ini sejalan dengan pendapat Luhmann bahwa trust hanya mungkin dapat tumbuh dalam situasi dimana kemungkinan kerusakan lebih besar daripada keuntungan yang didapatkan. Alasan untuk menerima risiko ekstra ini disebabkan keyakinan bahwa mitra tidak akan bertindak oportunis. Jadi, dalam situasi bisnis yang tidak menentu dan persaingan yang sangat ketat, kita tidak dapat menghindari dari keharusan untuk mempercayai orang lain untuk mempertahankan kedudukan kita dalam kompetisi. Keyakinan bahwa mitra kita tidak akan mengkhianati kita adalah pilihan yang tidak terhindarkan setelah berbagai pengalaman mengantarkan kita pada suatu keputusan untuk memberi trust. Lingkar orangorang kepercayaan inilah membentuk jaringan kerja dan koneksi yang saling mendukung dan mengukuhkan posisis dalam bisnis.

Relasi antara perusahaan dengan pihak pengguna jasa juga membutuhkan trust yang lebih luas, komprehensif dan kokoh. Oleh karena itu, trust disesuaikan dengan situasi hubungan perusahaan dan konsumen yang kompleks dan banyak aspeknya. Trust dirancang sedemikian rupa agar menjangkau konsumen yang luas. Oleh karena itu, trust dibangun dengan cara yang lebih masif; membuat iklan, mengeluarkan laporan laba rugi secara berkala dan transparan, mencantumkan data produk serta tanggal produksi dan kedaluarsa, pencantuman label halal bagi konsumen tertentu dan sebagainya. 
Semua hal ini dilakukan untuk menjaga trust. Bagaimanapun, sebagian besar relasi ekonomi didalamnya terdapat kombinasi antara trust dan sanksi.

Sanksi dan trust menurut Humphrey dan Schmitz (1998) beroperasi pada tiga level yang berbeda seperti yang ditunjukkan dalam Tabel berikut. Level makro atau sanksi yang bersifat personal berpotensi untuk diterapkan bagi seluruh transaksi antarfirma. Sanksi pada level meso dapat diterapkan pada bagian-bagian tertentu dari bidang usaha, lebih sering digunakan pada level sektoral. Sanksi pada level mikro diterapkan pada bidang usaha tertentu dan tergantung pada hubungan antara agen-agen tertentu pula.

\section{Tabel 1}

\section{SANKSI DAN TRUST}

\begin{tabular}{lll}
\hline & \multicolumn{1}{c}{ Sanksi } & \multicolumn{1}{c}{ Trust } \\
\hline Level Makro & Perjanjian kontraktual dan & Referensi bank \\
(Impersonal) & kekuatan hukum & Serfikat \\
Level Meso (Grup & Regulasi sektoral & Reputasi atas \\
atau sektor) & Kehilangan reputasi dalam & kejujuran/kompetensi \\
& grup & Trust berbasis karakter \\
Level Mikro & Kehilangan keuntungan masa & Trust berbasis proses: \\
(Personalisasi) & depan dari hubungan: & Pengalaman \\
& 'sandera' & transaksi/pertukaran \\
\hline
\end{tabular}

Sumber: Humphrey and Schmitz, Trust and Inter-Firm Relation in Developing and Transition Economic, 1998, hlm. 36

Sanksi yang paling jelas dalam hubungan antarfirma, pertama, adalah pernyataan yang tertera dalam kontrak tertulis, yang menyatakan syarat-syarat transaksi (terms of exchange) dan menyediakan perangkat hukum untuk melindungi masing-masing pihak. Kontrak sejenis ini merupakan standar dari praktik bisnis. Kedua, sanksi yang dapat diaplikasikan pada level meso. Aktifitas regulasi dari badan yang bersifat sektoral secara khusus sangat penting di sini. Dalam bank dan sektor finansial, sebagai contoh, melekatkan norma prosedural yang didesain untuk melindungi klien yang dapat dimonitor oleh pengawas. Di beberapa negara seperti Jerman misalnya, badan sektoral memainkan peran penting dalam penataan hubungan antarbadan usaha. Pada saat yang bersamaan, sanksi dalam menekan secara informal dalam jaringan kerja bisnis. Contoh yang paling nyata adalah konsekuensi hilangnya reputasi akibat kesalahan dalam bersikap. Para pengusaha, sebagai pelaku dalam kelompok berisiko ini tidak hanya akan kehilangan mitra kerja mereka, tetapi juga 
penolakan sosial dalam grup. Ketiga, sanksi mikro level dapat diterapkan pada transaksi yang sangat spesifik.

Pernyataan yang banyak dikutip dalam literatur adalah konsekuensi oportunisme terhadap income di masa depan yang berasal dari relasi bisnis. Hubungan yang menguntungkan dua pihak merupakan kepentingan yang dipelihara. Hubungan bisnis itu sendiri merupakan agunan terbaik dalam transaksi dan perkreditan. Pengamanan tambahan dapat dicapai dengan menggunakan 'sandera' (hostages) - kesepakatan yang memperkuat dirinya dengan menghukum segala bentuk tindakan oportunistik (ingin menguntungkan diri sendiri). Sanksi dan trust adalah alat kontrol yang mandiri dalam diri masingmasing pelaku bisnis. Kita sering menyaksikan bagaimana suatu kelompok, institusi maupun individu yang leading dalam bisnis atau sukses dalam menjalankan pekerjaan dan profesinya, pada dasarnya merekalah pihak yang mampu menghimpun dan melestarikan trust.

\section{HILANGNYA TRUST}

Beberapa kasus manipulasi keuangan dalam perusahaan papan atas di Amerika seperti skandal Enron dan Worldcom memperlihatkan tingkat kerentanan trust dalam korporasi. Waktu yang relatif sempit untuk menilai dan mengalkulasi serta sifat informasi yang asimestris terhadap satu pihak menyebabkan mitra seringkali tidak dimungkinkan untuk memonitor transaksi dan menilai apakah setiap persyaratan telah dipenuhi. Platteau (1994) dalam Humphrey dan Schmitz mengungkapkan pertanyaan penting 'Dalam dunia yang berciri khas imperfect information (informasi yang tidak sempurna) dan oportunisme bagaimana caranya untuk mengendalikan risiko dan menegakkan pertukaran yang efisien?'. Platteau dalam argumentasinya menyatakan bahwa kuncinya adalah pada individu. Jika secara individual tidak mempercayai satu sama lain bahwa masing-masing pihak akan memenuhi persyaratan atas kesepakatan yang mereka buat, mereka tidak akan melakukan pertukaran satu dengan yang lainnya. Oleh karena itu pertukaran sarat dengan nilai moral. Oportunisme dibatasi oleh moral normatif dan selanjutnya moralitas yang berlaku secara umum itulah menjadi esensi bagi pasar yang efektif. 
Jika kita contohkan dalam tulisan ini bagaimana perilaku oportunis pada akhirnya menyebabkan hancurnya keuntungan jangka panjang dan kelangsungan bisnis berskala raksasa Enron dan Worldcom yang runtuh di tahun 2002. Kedua perusahaan tersebut melaporkan laba yang sangat besar dan laporan keuangan yang sangat atraktif, seolah-olah Enron dan Worldcom adalah perusahaan yang sangat menjanjikan. Kebangkrutan tersebut pada dasarnya adalah konsekuensi dari perilaku oportunis dan keserakahan para pemilik modal dan akuntan publik bereputasi internasional Arthur Andersen. Andersen selain sebagai auditor juga konsultan keuangan perusahaan tersebut untuk meraup laba sebesar-besarnya dengan cara memanipulasi laporan keuangan dan penghancuran barang bukti berupa dokumen dan kertas kerja Enron. Andersen juga memberikan konsultasi keuangan kepada klien untuk memberi nilai tambah pada perusahaan. Publik merasa dibohongi, dan dampaknya Enron mengalami kebangkrutan karena dan nilai sahamnya langsung anjlok. Kebangkrutan Enron dan Worldcom juga menyeret auditornya kantor akuntan Arthur Andersen ke dalam kebangkrutan dan berdampak negatif pada sekitar 28.000 pegawainya di AS dan 85.000 pegawainya di dunia. Pada kasus manipulasi ini sanksi yang diterima adalah hilangnya trust secara ekonomi dan sekaligus sosial. Arthur Andersen yang awalnya adalah kantor akuntan terkemuka yang digolongkan Lima Besar Dunia harus menghadapi konsekuensi bahwa dunia mempertanyakan kejernihan hasil auditnya dan laporan keuangannya.

Kasus skandal Enron dan Worldcom serta Andersen menunjukkan betapa trust sangat rentan dalam kegiatan ekonomi yang semakin kompleks. Seringkali informasi tidak disampaikan sesuai dengan situasi yang sebenarnya. Dalam banyak hal kita seringkali harus mempercayai suatu mekanisme. Misalnya situasi yang memaksa bahwa tidak ada cara yang paling aman dan nyaman selain menyimpan uang di bank. Padahal kita hanya mengenal bank dari informasi yang disampai oleh bank dan orang-orang yang memiliki pengalaman berhubungan dengan bank. Prinsipnya, kita tidak mengetahui secara pasti kondisi sebenarnya, namun mau tidak mau kita harus memilih bank dengan mekanisme yang paling kita percaya dan tujuan kita menyimpan uang di bank tersebut tercapai. Yang terjadi dengan skandal Enron dan Worldcom adalah 
bagaimana mekanisme dan sistem akuntasi dijadikan alat untuk memanipulasi kesadaran dan membangun trust dengan menggunakan assymetric information. Assimetric information seringkali tidak disadari oleh masyarakat, maka, situasi ini menjadi kesempatan bagi para pelaku yang akses terhadap informasinya sangat kuat. Namun, jika situasinya tidak lagi dapat dikontrol karena mekanisme check and balance juga menjadi standar bagi terbentuknya trust dalam kegiatan ekonomi, maka saat kebohongan terungkap, trust akan langsung hilang. Semakin rasional tatanan pembentuk trust dalam ekonomi, maka trust muncul semakin kuat. Hal sebaliknya terjadi, jika ternyata rasionalitas dijadikan hanya sebagai alat dengan tujuan manipulatif, maka trust yang sudah terbangun dapat dengan mudah hancur dan sulit diperbaiki. Inilah pelajaran yang dapat diambil dari kecurangan-kecurangan dalam tindakan ekonomi.

\section{PUSTAKA ACUAN}

Chalid, Pheni. 2009. Trust: modal transaksi ekonomi dan relasi social. Jakarta: Center for Social Economic Studies

Fukuyama, F. 1995. Trust: The Social Virtues and the Creation of Prosperity, London: Hamish Hamilton

Granovetter and Swedberg (ed.). 1992. The Sociology of Economic Life, Boulder: San Francisco, Oxford: Westview Press

Humphrey, John dan Hubert Schmitz. Trust and Inter-Firm Relation in Developing and Transition Economies. Journal of World Development Studies, Vol.34, no. 4, April 1988

Jeffrey S. Kinsler, Arthur Andersen and the Temple of Doom, Kinsler Article (Final Macro), 2008, hlm. 3, source: http://www.swlaw.edu/pdfs/r/37 1kinsler.pdf diakses 23 April 2006.

Johnson, Doyle P. 1988. Teori Sosiologi Klasik dan Modern Buku ke-1, Jakarta: Gramedia Pustaka Utama

Johnson, Doyle P. 1990. Teori Sosiologi Klasik dan Modern Buku ke-2, Jakarta: Gramedia Pustaka Utama

Lyon, Fergus. Trust, Network and Norms: The Creation of Social Capital in Agricultural Economies in Ghana, World Development Vol. 28 No. 4, year 2000 
McDermott, John. 1991. Corporate Society; Class, Property and Contemporary Capitalism, Boulder: Westview Press

Polanyi, Karl. 1957. The Great Transformation, Boston: Beacon Press

Putnam, R.D. 1993. Making Democracy Works; Civic Tradition in Modern Italy. Princeton University Press

Slater, Don and Fran Tonkiss. 2000. Market Society and Modern Social Theory. Cambridge: Polity Press

Smelser, Neil J. 1976. The Sociology and Economic Life. New Jersey: Prentice Hall 